\title{
SIX3 wt Allele
}

National Cancer Institute

\section{Source}

National Cancer Institute. SIX3 wt Allele. NCI Thesaurus. Code C75555.

Human SIX3 wild-type allele is located within 2p16-p21 and is approximately $4 \mathrm{~kb}$ in length. This allele, which encodes homeobox protein SIX3, plays a role in retinal development. Mutations in this gene are associated with holoprosencephaly 2. 